\title{
PENINGKATAN KAPASITAS PRODUKSI USAHA RINTISAN "SEMESTA RASA" MELALUI PENERAPAN TEKNOLOGI TEPAT GUNA
}

\author{
Dimas Rahadian Aji Muhammad, Gusti Fauza', Dian Rachmawanti Affandi ${ }^{2}$ \\ ${ }^{1}$ Prodi Ilmu Teknologi Pangan, Fakultas Pertanian, Universitas Sebelas Maret \\ Jl. Ir. Sutami 36A Kentingan Surakarta 57126 \\ ${ }^{2}$ Prodi Teknologi Hasil Pertanian, Sekolah Vokasi, Universitas Sebelas Maret \\ Jl. Ir. Sutami 36A Kentingan Surakarta 57126
}

Email: dimasrahadian@staff.uns.ac.id; gustifauza@staff.uns.ac.id; dianrachmawanti@staff.uns.ac.id

\begin{abstract}
Abstrak
Desa Putat, Kecamatan Patuk merupakan salah satu daerah penghasil kakao di Kabupaten Gunungkidul dengan total 11 hektar lahan yang ditanami lebih dari 10 ribu pohon kakaoUntuk meningkatkan nilai tambah produk kakao yang dihasilkan di desanya, pada Tahun 2019 para pemuda di Desa Putat mendirikan unit usaha pengolahan kakao dengan nama UKM Semesta Rasa dengan produk makanan ringan berbasis cokelat, dengan produk andalannya adalah ampyang cokelat. Hasil survey dari Tim Pengabdian Masyarakat UNS menunjukkan bahwa produk hasil olahan cokelt dan kakao tersebut belum berkualitas baik karena masih melakukan proses pengolahan menggunakan peralatan dengan kapasitas kecil serta pengetahuan dasar terkait proses pengolahan pangan masih rendah. Sebagai upaya untuk menyelesaikan masalah tersebut, Tim Pengabdian Masyarakat UNS telah bersepakat dengan mitra untuk menyelenggarakan program berupa (1) Introduksi ilmu dan teknologi pengolahan kakao; (2) Fasilitasi teknologi tepat guna untuk pengolahan kakao menjadi produk cokelat siap jual; (3) Training kewirausahaan dan manajemen industri pangan. Hasil evaluasi terhadap kegiatan yang dilakukan menunjukkan bahwa penerapan teknologi tepat guna berupa oven dan mixer dapat meningkatkan kapasitas produksi lebih dari 3x lipat per batch proses. Program pelatihan yang dilakukan dapat meningkatkan kapasitas sumber daya manusia pada usaha rintisan tersebut pada aspek teknologi pengolahan kakao, kewirausahaan dan manajemen industri pangan
\end{abstract}

Kata Kunci: kakao, usaha rintisan, teknologi tepat guna, Gunungkidul

\section{PENDAHULUAN}

Desa Putat, Kecamatan Patuk merupakan salah satu daerah penghasil kakao di Kabupaten Gunungkidul dengan total 11 hektar lahan yang ditanami lebih dari 10 ribu pohon kakao. Tercatat, jumlah kapasitas panen mencapai $400 \mathrm{~kg}$ kakao kering setiap minggunya. Sejauh ini, sebagian besar hasil panen kakao dijual dalam bentuk mentah dengan nilai tambah produk yang relatif kecil. 
Untuk meningkatkan nilai tambah produk kakao yang dihasilkan di desanya, pada Tahun 2019 para pemuda di Desa Putat mendirikan unit usaha pengolahan kakao dengan nama UKM Semesta Rasa. UKM ini telah mampu membuat produk makanan ringan berbasis cokelat, dengan produk andalannya adalah ampyang cokelat dengan brand "Rarugi".

Para pendiri UKM Semesta rasa ini sebenarnya adalah putra-putri dari para petani di Desa Putat. UKM ini dapat dianggap sebagai lini hilir dari Kelompok Tani Sido Dadi. UKM ini telah mampu menghasilkan produk seperti coklat Batangan, dodol cokelat, keripik pisang salut cokelat dan ampyang cokelat. Jumlah pemudapemudi yang dipekerjakan berjumlah adalah 6 orang. Namun, hasil survey dari Tim Pengabdian Masyarakat UNS menunjukkan bahwa produk hasil olahan cokelat dan kakao tersebut perlu perbaikan pada beberapa aspek.

Beberapa faktor yang menyebabkan hal ini antara lain sumber daya manusia yang didominasi oleh ibu rumah tangga serta petani kakao yang belum memiliki pengetahuan tentang pengolahan makanan yang baik, serta peralatan yang digunakan masih terbatas yaitu menggunakan peralatan yang biasanya dipakai untuk kegiatan rumah tangga sehari-hari. Sumber daya manusia yang bekerja pada proses hilir masih minim penguasaan ilmu dan teknologi pengolahan cokelat, sehingga menyebabkan pengolahan hasil yang belum maksimal. Padahal UKM Semesta Rasa mempunyai pangsa pasar yang sangat prospektif, sebab lokasinya terletak di sekitar Kawasan Wisata Utama di Gunung Kidul, yang banyak dikunjungi wisatawan baik lokal maupun mancanegara, yaitu Bukit Bintang, Embung Nglangeran, Gunung Api Purba Nglangeran, dan Goa Pindul.

Sebagai upaya untuk menyelesaikan masalah tersebut, Tim Pengabdian Masyarakat UNS telah bersepakat dengan mitra untuk menyelenggarakan beberapa program, di antaranya berupa introduksi ilmu dan teknologi pengolahan kakao dan fasilitasi teknologi tepat guna untuk peningkatan kapasitas produksi.

\section{METODE}

Sebagai upaya untuk menyelesaikan hal-hal yang menjadi permasalahan UKM Semesta Rasa, dilakukan introduksi ilmu dan teknologi pengolahan kakao dan fasilitasi teknologi tepat guna untuk peningkatan kapasitas produksi.

Tahap pertama kegiatan pengabdian masyarakat ini dilakukan pelatihan dasar-dasar pengolahan cokelat. Referensi penanganan pasca panen yang diacu untuk kegiatan pengabdian masyarakat ini adalah artikel dari Hinneh et al. (2019) sedangkan teknologi pengolahan kakao yang diacu adalah artikel dari Saputro et al. (2017). Pada tahapan konfeksioneri, referensi yang diacu adalah artikel dari Muhammad et al. (2018). Beberapa tahapan penting yang akan menjadi materi training adalah proses fermentasi (yang bertujuan untuk membentuk senyawa bakal flavaour), pengeringan (untuk menurunkan kadar air biji kakao), penyangraian (untuk membentuk senyawa flavour daroi senyawa precursor flavour), penggilingan (untuk membuat kakao pasta), pencampuran (untuk mencampurkan bahan lain agar mendapatkan spesifikasi cokelat sesuai dengan yang diinginkan), refining (untuk mengecilkan ukuran partikel pada cokelat), serta tempering (untuk membentuk kristal cokelat yang baik). Ketika produk cokelat yang baik sudah diperoleh, maka selanjutnya dilakukan pelatihan pengembangan produk-produk turunan cokelat, termasuk snack bersalut cokelat.

Tahap kedua dari kegiatan ini adalah fasilitasi teknologi tepat guna untuk peningkatan kapasitas produksi. Beberapa peralatan yang diperbantukan untuk menyelesaikan masalah di UKM Semesta Rasa antara lain: (1) Oven (digunakan untuk proses pemanggangan ampyang, guna mencukupi target produksi $10 \mathrm{~kg}$ per hari, dimana kapasitas saat ini hanya terbatas di $2 \mathrm{~kg}$ per hari); (2) Heavy duty blender (digunakan untuk menghaluskan biji kacang tanah dan biji mete, sebab untuk saat ini masih dilakukan manual dengan mengunakan penghalus kayu; (3) Turbo grande mixer (digunakan untuk mencampurkan adonan ampyang secara merata); (4) Hand sealer (digunakan untuk menutup kemasan dan 
memastikan rapat sehingga udara tidak masuk kedalam kemasan yang akan mempengaruhi kualitas produk); (5) Timbangan Digital (digunakan untuk menimbang bahan-bahan sehingga sesuai resep produksi); (6) Lemari dan showcase (digunakan untuk menyimpan peralatan dan produk sehingga mampu dikontrol penggunaannya dan dijaga kebersihannya); (7) stainless steel kitchen utensil (digunakan untuk proses pengolahan); serta (8) apron / celemek dan sarung tangan (digunakan sebagai APD untuk menjamin kebersihan dan perlindungan diri (personal hygine sebagai syarat kemananan pangan).

\section{HASIL DAN PEMBAHASAN}

\section{Introduksi Ilmu dan Teknologi Pengolahan Kakao}

Pembuatan produk produk-produk turunan coklat yang selama ini dilakukan belum sesuai standar kelimuan teknologi pangan sehingga banyak mempengaruhi pada kualitas produk yang dihasilkan. Sebagai contoh adalah proses penyangraian dan tempering yang kurang baik. Tempering mempengaruhi proses kristalisasi pada permukaan coklat sehingga hal ini yang kemudian menjadi issue tersendiri terhadap proses di unit produksi olahan coklat, jika kristaliasi tidak berjalan baik maka cokelat tidak akan terlihat mengkilap (shinny) sesuai standar mutu produk cokelat yang baik dan juga ekspektasi dari konsumen.

Introduksi ilmu dan teknologi pengolahan kakao dimulai dari aspek pasca panen hingga aspek penyimpanan. Disampaikan kepada mitra kegiatan bahwa kualitas kakao sebagai bahan baku dari cokelat mempunyai peran yang signifikan dalam menentukan kualitas produk yang dihasilkan. Area tempat mitra kegiatan pengabdian masyarakat ini memiliki kebun dengan luas 11 hektar yang ditanami berbagai klon unggulan kakao seperti MCC 01, MCC 02, Criolo, Forastero, Lindak, ICCRI 03, ICCRI 04, ICCRI 07, Masamba dan KKM (Yunindanova et al., 2011). Namun demikian, kualitas biji tidak cukup dalam menentukan kualitas produk sebab aspek pasca panen dan pengolahan juga mempunyai peran yang signifikan.

Disampaikan kepada mitra kegiatan, bahwa penanganan pasca panen yang baik meliputi pemecahan buah kakao menggunakan benda tumpul (untuk mencegah luca pada biji kakao), fermentasi (untuk membentuk prekursoe-prekursor senyawa bakal citarasa pada cokelat) serta pengeringan (untuk mengentikan reaksi biokimiawi dan menurunkan kadar air agar biji tidak mudah terserang mikroorganisme).

Pada aspek pengolahan, ditekankan pada pentingnya proses penyangraian (untuk membentuk senyawa citarasa dari prekursor citarasa yang dihasilkan selama fermentasi), penggilingan (untuk mengecilkan ukuran biji kakao menjadi berbentuk pasta) serta pencampuran dengan bahan lain (untuk menghasilkan karakteristik rasa yang diinginkan). Proses pencampuran ini tidak terbatas pada proses pencampiuran antara pasta cokelat dengan gula, namun dengan bahan lain seperti kacang-kacangn dalam membuat ampyang cokelat atau dengan cokelat komersial untuk menurunkan harga jual. Tempering juga menjadi pokok bahasan yang didiskusikan dalam kegiatan ini, karena tempering memerlukan teknik perlakuan dengan suhu tertentu agar menghasilkan produk cokelat dengan karaktersitik yang baik, yaitu mengkilat dan tidak mudah meleleh. Selain aspek teknis pengolahan, dasar-dasar Cara Produksi Pangan Olahan yang Baik (CPPOB) untuk UMKM juga didiskusikan agar produk yang dihasilkan aman dan konsistensi kualitasnya dapat dipertahankan. Kegiatan introduksi ilmu dan teknologi pengolahan kakao menjadi produk snack yang siap dipasarkan tidak sebatas pada teori di kelas, namun juga disertai praktek.

Kegiatan sosialisasi dilakukan dengan bahasa yang sederhana dan mudah dimengerti oleh mitra sebab pelaku usaha "Semesta Rasa" terdiri dari para pemuda-pemudi yang tidak berlatar ilmu pangan. Beberapa di antara nya juga terdapat ibu rumah tangga yang turut hadir dalam kegiatan. Dokumentasi kegiatan introduksi ilmu dan teknologi pengolahan kakao ditunjukkan pada Gambar 1. 


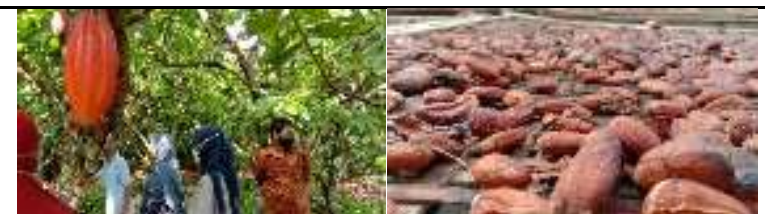

(A)

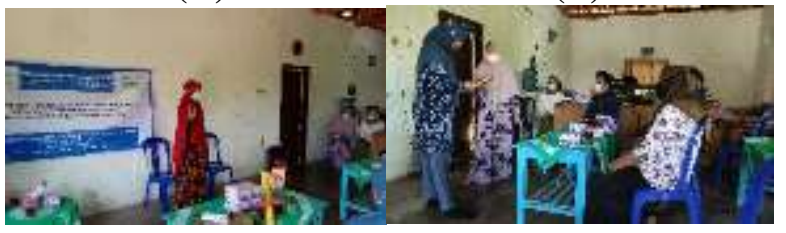

(C)

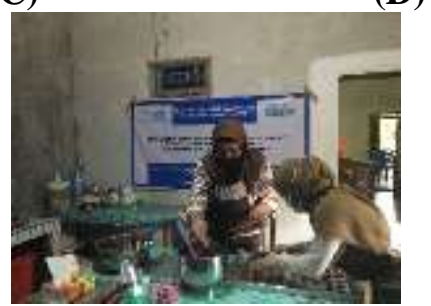

(E)

Gambar 1. Kegiatan introduksi ilmu dan teknologi pengolahan kakao. (A) Penjelasan terkait pengaruh kualitas biji kakao terhadap kualitas produk cokelat;

(B) Penjelasan terkait pengaruh pascapanen terhadap kualitas produk cokelat; (C) Sosialisasi ilmu dan teknologi pengolahan kakao dan Cara Pengolahan Pangan Olahan yang Baik; (D) Diskusi interaktif dengan peserta dan evaluasi kegiatan (E) Praktek pembuatan produk

\section{Fasilitasi Teknologi Tepat Guna untuk Peningkatan Kapasitas Produksi}

Peralatan proses pengolahan sangat berpengaruh terhadap kualitas produk yang dihasilkan terutama pada produk-produk hasil turunan cokelat. Maka dari itu, peralatan dengan kualitas dan kuantitas yang memadai sangat diperlukan. Fasilitasi teknologi tepat guna untuk peningkatan kapasitas produksi merupakan salah satu strategi yang diterapkan untuk menjamin keberhasilan dari program kegiatan pengabdian masyarakat ini.

Peralatan yang dihibahkan sekaligus digunakan sebagai alat pelatihan akan ke mitra UKM Semesta Rasa antara lain oven, heavy duty blender, turbo grande mixer, hand sealer, timbangan digital, lemari penyimpanan dan showcase, stainless steel kitchen utensil, fasilitas personal hygine, serta kompor gas. Peralatan yang dihibahkan merupakan peralatan yang mendesak diperlukan oleh UKM Semesta Rasa dan sudah disepakati bersama dengan Tim Pengabdian Masyarakat UNS sejak awal penyusunan proposal.

Fasilitasi peralatan produksi ini penting agar tidak ada kendala modal usaha bagi mereka ketika mengimplementasikan ilmu dan teknologi pengolahan produk pangan yang diintroduksikan ke mitra oleh Tim Pengabdian Masyarakat UNS. Dokumentasi kegiatan fasilitasi teknologi tepat guna untuk peningkatan kapasitas produksi pada Gambar 2.

Komunikasi intensif dengan mitra dalam pengadaan alat, termasuk survey dan pembelian peralatan yang dilakukan bersama dengan mitra sangat penting, sebab mitra merupakan pihak yang memahami peralatan yang dibutuhkan dalam proses produksi. Hal ini dapat menjamin kebermanfaatan dari peralatan yang dihibahkan. Telah jamak diketahui bahwa pada berbagai program hibah peralatan kepada masyarakat, program tersebut bersifat top-down yaitu menyesuaikan program dan anggaran yang dimiliki oleh pemberi hibah. Dalam kondisi seperti ini, peralatan yang dihibahkan beresiko tidak bermanfaat bagi masyarakat penerima hibah, misalnya karena terkendala kapasitas yang terlalu besar atau biaya operasional yang tidak sesuai dengan kondisi masyarakat yang dibantu.

Dalam kegiatan ini, peningkatan kualitas, kuantitas dan kapasitas peralatan produksi terlihat secara nyata.Peningkatan kualitas dan kuantitas peralatan produksi misalnya terjadi pada fasilitas personal hygine dan kompor gas. Pada awalnya UKM Semesta Rasa menggunakan fasilitas personal hygine, kitchen utensil dan kompor gas yang masih sharing dengan keperluan rumah tangga. Namun dengan adanya kegiatan ini fasilitas personal hygine, kitchen utensil dan kompor gas sudah dimiliki sendiri sebagai asset dari UKM Semesta Rasa dan mempunyai kualitas yang lebih baik 
daripada yang sebelumnya digunakan di UKM tersebut.

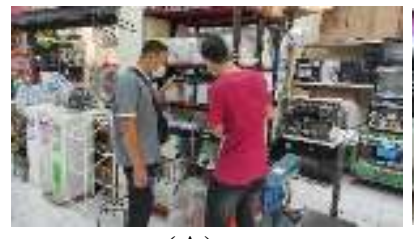

(A)

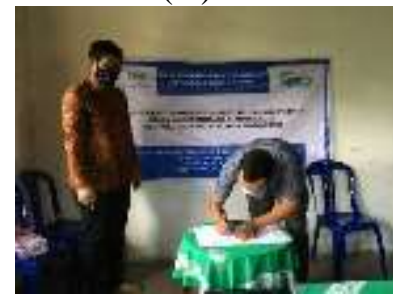

(C)

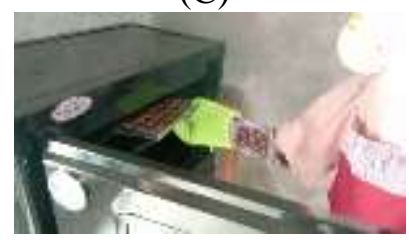

(E)

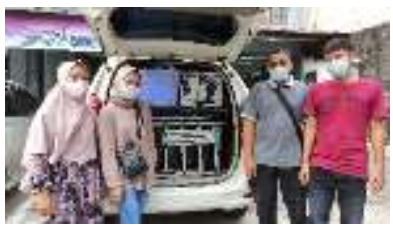

(B)

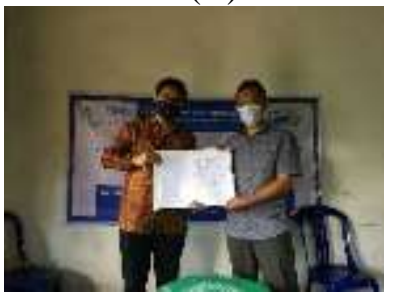

(D)

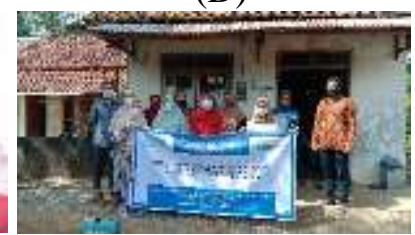

(F)

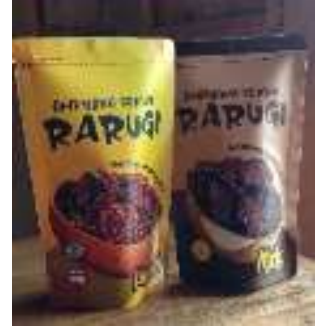

(G)

Gambar 2. Kegiatan fasilitasi teknologi tepat guna untuk peningkatan kapasitas produksi. (A) Pembelian dan pengadaan teknologi tepat guna bersama mitra; (B) Pengangkutan peralatan ke lokasi kegiatan pengabdian masyarakat; (C) Serah terima secara resmi peralatan yang diperbantukan kepada mitra; (D) Dokumen serat terima bantuan peralatan; (E) Penggunaan peralatan bantuan untuk proses pengolahan dan produksi makanan; (F) Foto bersama Tim Pengabdian Masyarakat UNS dengan mitra pengabdian UKM Semesta Rasa; (G) Produk ampyang cokelat UKM "Semesta Rasa" dengan Brand Rarugi.
Peningkatan kapasitas produksi terlihat dari keberadaan oven, heavy duty blender dan turbo grande mixer. Sebelum kegiatan pengabdian masyarakat ini dilakukan, oven yang digunakan adalah oven kompor tangkring dengan dimensi $38 \times 38 \times 38 \mathrm{~cm}$. Sedangkan oven yang diadakan dalam kegiatan pengabdian masyarakat ini berukuran 80 × 44 × $65 \mathrm{~cm}$ yang dilengkapi dengan pemantau suhu. Sebelum kegiatan pengabdian masyarakat, UKM Semesta Rasa membuat adonan secara manual, namun setelah kegiatan pengabdian masyarakat keberadaan turbo grande mixer membuat proses pengadonan menjadi lebih mudah dan efisien. Apabila dilakukan perhitungan, maka telah terjadi peningkatan kapasitas produksi menjadi 3 kali lipat per jam.

\section{Evaluasi dan Keberlanjutan}

Setelah kegiatan introduksi ilmu dan teknologi pengolahan kakao dan fasilitasi teknologi tepat guna untuk peningkatan kapasitas produksi, data dikumpulkan melalui wawancara untuk mendapatkan respon mitra. Dari 15 peserta yang hadir, keseluruhan menyatakan bahwa kegiatan sosialisasi memberi manfaat dan memberikan banyak informasi baru terkait dengan teknologi pengolahan kakao dan cokelat. Tabel 1 menunjukkan hasil evaluasi kegiatan peningkatan kapasitas produksi usaha rintisan "Semesta Rasa" melalui penerapan teknologi tepat guna.

Tabel 1 juga memunjukkan bahwa mitra mengharapkan ada keberlanjutan dari program kegiatan pengabdian kepada masyarakat ini. Beberapa kegiatan yang dapat dilakukan untuk melanjutkan kegiatan ini antara lain training komprehensif kewirausahaan serta fasilitasi perijinan dan pemasaran produk.

Adanya industri pangan skala kecil UKM Semesta Rasa yang diprakarsai para pemudapemudi ini menunjukkan potensi kemandirian masyarakat desa dalam mengembangkan dan meningkatkan ekonomi. Terlebih lagi, usaha 
rintisan tersebut dilakukan dengan memberdayakan masyarakat, SDM serta potensi alam yang ada sehingga produk tersebut memiliki nilai jual yang ekonomis. Namun demikian, UKM ini masih mengalami kendala dalam hal manajemen industri pangan. Beberapa materi pokok yang akan diberikan, antara lain sebagai bagian dari training komprehensif kewirausahaan meliputi motivasi bagi wirausaha pemula, termasuk di dalamnya pembuatan business canvas model, sanitasi dan keamanan pangan industri berbasis hasil pertanian, analisis ekonomi industri pangan skala kecil serta manajemen pembukuan industri pangan kecil.

Tabel 1. Hasil evaluasi kegiatan Peningkatan Kapasitas Produksi Usaha Rintisan "Semesta Rasa" Melalui Penerapan Teknologi Tepat Guna

\begin{tabular}{lll}
\hline \multicolumn{1}{c}{$\begin{array}{c}\text { Komponen } \\
\text { Evaluasi }\end{array}$} & Sebelum Kegiatan & Sesudah Kegiatan \\
\hline $\begin{array}{l}\text { Pengetahuan } \\
\text { terkait ilmu } \\
\text { dan teknologi } \\
\text { pengolahan } \\
\text { kakao }\end{array}$ & $\begin{array}{l}\text { Mengerti sebagian } \\
\text { aspek }\end{array}$ & $\begin{array}{l}\text { Terjadi } \\
\text { peningkatan } \\
\text { pemahaman dan }\end{array}$ \\
Fasilitas & Kurang & $\begin{array}{l}\text { memangdang } \\
\text { penting }\end{array}$ \\
Pengolahan & & Terjadi \\
& & $\begin{array}{l}\text { peningkatan } \\
\text { secara kuantitas, } \\
\text { kualitas dan } \\
\text { kapasitas }\end{array}$ \\
& & Bermanfaat \\
Manfaat & - & Diharapkan \\
Keberlanjutan & - & berlanjut \\
\hline
\end{tabular}

Fasilitasi perijinan dan pemasaran produk yang meliputi dokumen legalitas usaha dan peningkatan promosi melalui digital dan offline market juga merupakan aspek penting yang perlu ditingkatkan sebagai bagian dari keberlanjutan program pengabdian masyarakat ini. Untuk menjamin keberlangsungan usaha, maka diperlukan legalitas usaha, selain P-IRT yang sudah dimiliki UKM Semesta Rasa. Hal yang dipandang perlu adalah mendaftarkan legalitas HKI merk dagang serta melengkapi tabel kandungan gizi pada produk tersebut. Terlebih lagi, akhir-akhir ini banyak kompetisi wirausaha yang mensyaratkan legalitas usaha menjadi prasyarat partisipasi, misalnya Food Starti Up Indonesia yang diinisiasi oleh Kementerian Pariwisata dan Ekonomi Kreatif. Selanjutnya, kegiatan pengabdian masyarakat dapat dilanjutkan dengan Pelatihan pemasaran berbasis IT dan strategi Direct Selling. Dasar dari pelatihan ini adalah menggunakan atau pemanfaatan IT sebagai sarana pemasaran dan penjualan produk melalui berbagai jejaring sosial yang tersedia. Banyaknya pengguna jejaring sosial menjadi pasar tersendiri yang bisa digarap dari segi pemasaran produk. Pemasaran dengan memanfaatkan teknologi IT ini sangat menguntungkan sebab produk tersebut tidak hanya dikenal di sekitar lingkungan namun mampu menjangkau lapisan masyarakat yang lebih luas lagi. Pelatihan ini akan berjalan jika pelaku UMKM di Desa Putat mengetahui tentang bisnis online serta terampil dalam mengelola jejaring tersebut.

Pengembangan masyarakat yang sudah diprakarsai oleh para pemuda di lingkungan perkebuanan kakao ini patut untuk diteruskan. Hasil penelitian Praseptiangga et al., (2020) menunjukkan bahwa banyak tantangan yang dihadapi dalam membangun dan mempertahankan agroindustri cokelat di Indonesia. Salah satu faktor yang teridentifikasi adalah generasi muda putra petani kakao sudah tidak tertarik untuk melanjutkan untuk menjadi petani dan mengelola kebun kakao. Hal ini terjadi karena incomeyang didapatkan oleh petani kakao relative kecil. Salah satu cara untuk mempertahankan perkebunan kakao ini adalah dengan meingkatkan nilai tambah kakao dengan menjadikan kakao menjadi produk-produk turunan yang bernilai jual tinggi. Keberadaan UKM berbasis komoditas kakao ini dapat berpotensi mempertahankan eksistensi perkebunan kakao, sebab UKM tersebut membutuhkan bahan baku biji kakao.

Pemberdayaan masyarakat dengan transformasi dari sebatas masyarakat petani menjadi masyarakat petani dan industri akan turut mendukung 
pembangunan yang bertujuan untuk kemncapai kesejahteraan. Untuk menjamin keberhasilan dari pemberdayaan masyarakat dalam jangka Panjang, maka partisipasi masyarakat sejak awal diperlukan. Masyarakat bukan hanya sebagai objek kegiatan pemberdayaan masyarakat, tetapi juga menjadi subjek kegiatan. Dengan kata lain, pelibatan masyarakat dalam pembangunan lebih mengarah kepada bentuk partisipasi, bukan dalam bentuk mobilisasi. Perguruan tinggi, dalam hal ini adalah UNS, bertidak sebagai fasilitator yang menjadi penghubung antara kebutuhan dan keinginan masyarakat dengan akses ilmu dan pendanaan. Partisipasi masyarakat sangat diperlukan dalam perumusan program dan pengadaan peralatan, seperti yang telah dilakukan pada kegiatan ini, sehingga masyarakat merasa ikut memiliki dan bertanggung jawab terhadap keberhasilan dan keberlangsungan program tersebut secara jangka panjang. Pelibatan masyarakat ini juga akan mampu menumbuhkan motivasi dan kreatifitas yang lebih bagi partisipasi pada tahap-tahap berikutnya. Salah satu cara yang dapat dilakukan untuk membangun partisipasi masyarakat adalah komunikasi yang intensif. Keberadaan teknologi dan aplikasi komunikasi saat ini, seperti WhatsApp ${ }^{\mathrm{TM}}$ dan Telegram ${ }^{\mathrm{TM}}$ dapat dimanfaatkan sebagai saran untuk membangun komunikasi yang intensif dan efektif.

\section{KESIMPULAN}

UKM Semesta Rasa mengalami peningkatan pengetahuan teknologi pengolahan kakao serta peningkatan kapasitas produksi. Respon terkait diseminasi teknologi pengolahan dinilai memberikan dampak positif dan manfaat pada peningkatan dan kestabilan kualitas produk. Selain itu, dengan adanya fasilitasi peralatan pengolahan secara signifikan meningkatkan kapasitas menjadi tiga kali lipat. Fasilitas peralatan pengolahan dari Tim Pengabdian Masyarakat Universitas Sebelas Maret berkontribusi besar dalam menggantikan peralatan pengolahan yang biasa digunakan untuk masak sehari-hari. Mitra menyatakan kebermanfaatan kegiatan ini dan keinginan untuk kegiatan berkelanjutan. Direkomendasikan bahwa kegiatan ini dilanjutkan dengan tahapan selanjutnya yaitu meliputi manajemen industri pangan dan pemasaran.

\section{UCAPAN TERIMAKASIH}

Terima kasih kepada Universitas Sebelas Maret yang telah mendanai kegiatan ini melalui Surat Perjanjian Penugasan Nomor: 261/UN27.22/HK.07.00/2021 dan UKM Semesta Rasa yang telah menjadi mitra kegiatan.

\section{REFERENSI}

Hinneh, M., Abotsi, E. E., Van de Walle, D., Tzompa-Sosa, D. A., De Winne, A., Simonis, J., ... \& Dewettinck, K. (2019). Pod storage with roasting: a tool to diversifying the flavor profiles of dark chocolates produced from 'bulk' cocoa beans?(Part I: aroma profiling of chocolates). Food Research International, 119, 84-98.

Muhammad, D. R. A., Saputro, A. D., Rottiers, H., Van de Walle, D., \& Dewettinck, K. (2018). Physicochemical properties and antioxidant activities of chocolates enriched with engineered cinnamon nanoparticles. European Food Research and Technology, 244(7), 1185-1202.

Praseptiangga, D., Zambrano, J. M. G., Sanjaya, A. P., \& Muhammad, D. R. A. (2020). Challenges in the development of the cocoa and chocolate industry in Indonesia: A case study in Madiun, East Java. AIMS Agriculture and Food, 5(4), 920-937.

Saputro, A. D., Van de Walle, D., Aidoo, R. P., Mensah, M. A., Delbaere, C., De Clercq, N., ... \& Dewettinck, K. (2017). Quality attributes of dark chocolates formulated with palm sap-based sugar as nutritious and natural alternative sweetener. European Food Research and Technology, 243(2), 177-191.

Yunindanova, M. B., Muhammad, D. R. A., \& Prabawa, S. (2021). Peningkatan Kualitas dan Kuantitas Biji Kakao Melalui Intensifikasi Perawatan Kakao, Introduksi Alat Budidaya, dan Pengering Sistem Hybrid. Abdihaz: Jurnal Ilmiah Pengabdian pada Masyarakat, 3(1), 8-15. 